\title{
Project SUPRASYD 1994 - Ketilidian supracrustal rocks in South-East Greenland and gold-bearing shear zones in the Julianehåb batholith
}

\author{
Adam A. Garde and Hans Kristian Schфnwandt
}

The SUPRASYD project is a reassessment of the geotectonic setting and mineral potential of the Lower Proterozoic Ketilidian orogenic belt in southern Greenland (previously described by Allaart, 1976 and Kalsbeek et al., 1990), and in particular its supracrustal rocks. During the first field season in 1992 a geological and geochemical reconnaissance programme was carried out in South-East Greenland between approximately latitudes $60^{\circ}$ to $62^{\circ} \mathrm{N}$, mainly in areas with supracrustal rocks (Steenfelt et al., 1992; Nielsen et al., 1993; Chadwick et al., 1994a). The second season in 1993 focused on the southern part of the Julianehåb batholith on the west coast of South Greenland, as well as on shear zones with spatially associated gold mineralisation (Garde \& Schønwandt, 1994; Chadwick et al., 1994b; Stendal et al., in press). Field work from the early 1960s was re-evaluated and supplemented with new mapping with the aim of compilation of the 1:100 000 scale map sheet 60 V.3, Søndre Sermilik.

This report presents a brief outline of the third season of the project in 1994. Two regions were visited, that between Kangerluluk and Lindenow Fjord in South-East Greenland, and the area around Søndre Sermilik on the west coast of South Greenland (Fig. 1). In the former region systematic mapping of the area covered by the map sheet Lindenow Fjord $60 \varnothing$. 1 was initiated, and in the latter field work for the Søndre Sermilik map sheet was completed. The geological reconnaissance was carried out in six weeks of July and August, supported by a chartered helicopter. Eight geologists from GGU, the University of Copenhagen, the University of Exeter (U.K.), the Geological Survey of Canada and the Geological Survey of Western Australia participated in the project.

\section{Supracrustal rocks between Kangerluluk and Lindenow Fjord in South-East Greenland}

The survey in 1992 of this area had revealed that the published geological map at scale 1:500 000 (Allaart, 1975) needed substantial revision. In addition, new interpretations of the Julianehåb batholith and associated major shear zones in the west arising from field work in 1993 indicated the need for further work in the eastern part of the orogen. The aims of the 1994 work in South-East Greenland were to obtain comprehensive information about: (a) the boundary relationships between the batholith and the supracrustal rocks; (b) the general stratigraphy and structure of the supracrustal rocks; and (c) their economic potential. In addition, an age determination programme was initiated in order to gather new information about the evolution of the Ketilidian orogen, especially the accretion of the batholith and the provenance of the supracrustal rocks east of it.

Field work was concentrated between Kangerluluk and Lindenow Fjord, an area that spans the boundary zone between the batholith and the supracrustal rocks to the south-east. The terrain is generally difficult of access and hostile. Most of the region consists of elevated plateaus covered by the Inland Ice, and the bedrock mostly crops out as nunataks and on steep slopes along the fjords. Only small areas in the vicinity of some of the fjords and near the outer coast are walkable, and access by boat is often prevented by ice conditions. One of the mapping teams was entirely occupied with systematic helicopter-supported mapping of the high ground. Another team made more detailed observations on foot between Danell Fjord and Paatusoq, and north of outer Lindenow Fjord, while a third team operated by rubber dinghy, combining coastline mapping with surveys of rust zones and follow-up of gold anomalies from the 1992 field season. A fourth team collected geological specimens for age determinations.

The results of the field work in 1994 are best presented within the framework of the recent reinterpretation of the Ketilidian orogen by Chadwick \& Garde (in press); it is considered to be a collisional orogen formed in a sinistral transpressional setting between a northern continent (the Archaean block of southern Greenland) and a southern ocean that was subducted towards the north. The orogen is divided into four zones (Fig. 1): (1) a border zone to the north-west, (2) the Julianehåb batholith, and an accretionary intra- and fore-arc basin to the south-east consisting of (3) a psammite and (4) a pelite zone (Fig. 1); the batholith, psammite and pelite zones proposed by Chadwick \& Garde replace the granite and folded migmatite zones of Allaart (1976). The first preliminary results of the new age determination programme are in agreement with the proposed plate-tectonic model of the orogen, confirming that both undeformed and gneissic parts of the Julianehåb 


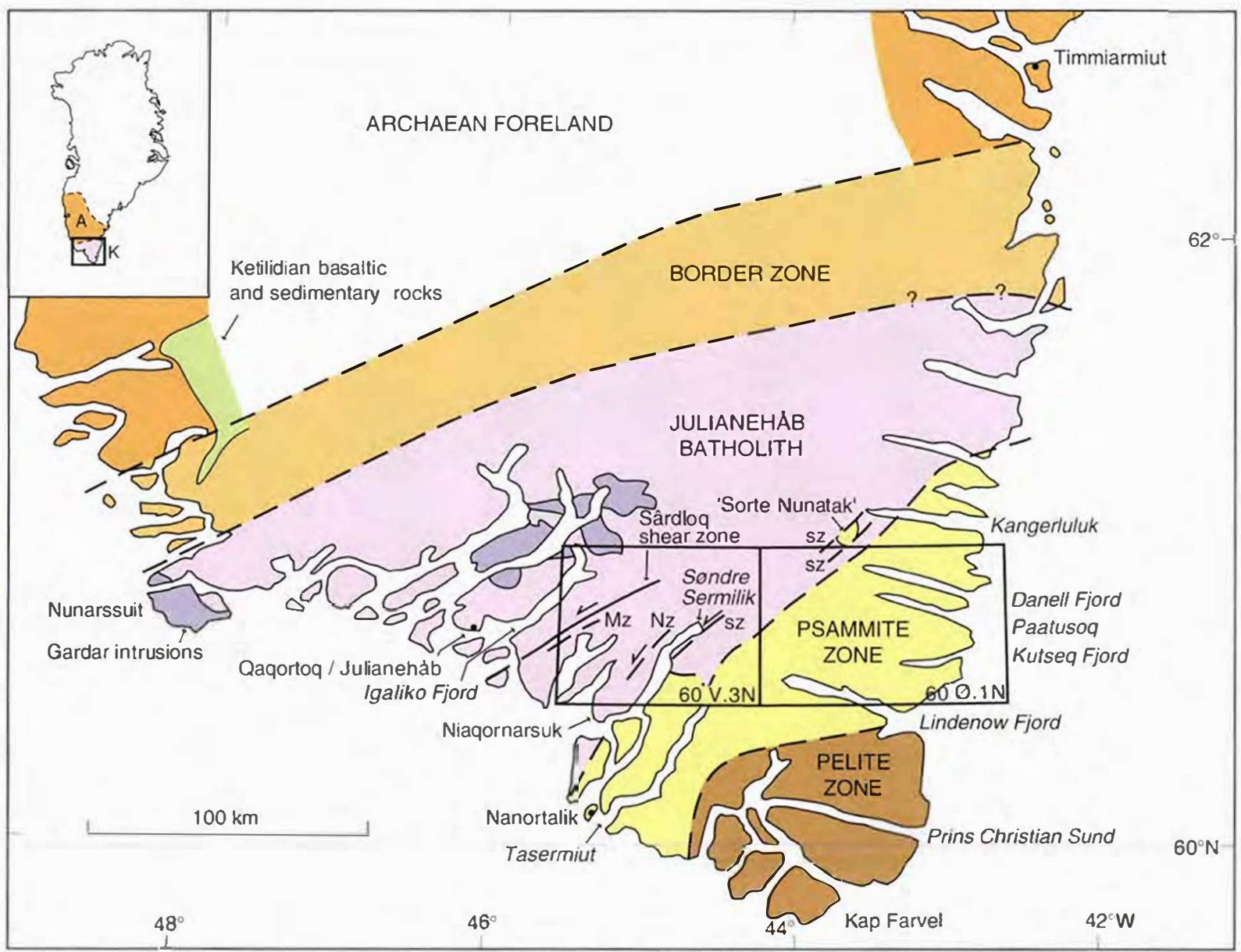

Fig. I. Sketch map of South Greenland (ice cap omitted), showing the areas of field work in 1994 within the two map sheet areas Sondre Sermilik 60 V. $3 N$ and Lindenow Fjord $6(0) \varnothing . I N$, and the principal divisions of the orogen. Much of the orogen is covered by the Inland Ice. M\%: Matorsuag high strain zone, Nz: Nanisiag shear zone, s\%: shear zone. The index map shows the Archacan hlock (A) and the Ketilidian orogen (K). Simplified from Chadwick \& Garde (in press).

batholith are of juvenile Proterozoic origin, and that detrital zircons in the fore-arc basin are mainly Proterozoic in age.

The field work in 1994 contirmed that the flat-lying lowgrade melavolcanic and clastic metasedimentary rocks in the 'Sorte Nunatak' area, found in 1992 west of Danell Fjord, are separated firom the Julianelsáb batholith by a sinistral transcurrent shear zone. It was also confirmed that the lowermost of these supracrustal rocks are intruded by a granite batholith. Between Danell Fjord and Kangerłuluk there are other broadly similar units of that-lying metavolcanic rocks, polymict conglomerates and cross-hedded psammites, which are interleaved with marginal parts of the batholith. Some of the metavolcanic units contain excellently preserved agglomerates, flows, hyaloclastites. slumped volcaniclastic conglomerates and cross-bedded tuffites. The contacts between the batholith and supracrustal rucks appear to be steep shear zones as in the 'Sorte Nuna- lak" area, but outcrops are sporadic. The variety of rock types found in the north-western part of the psammite zone together indicate a tectonically unstable near-shore environment with localised calc-alkaline volcanism (T. F. D. Nielsen, pers. comm., 1994), and this part of the psammite zone is therefore interpreted as proximal with respect to the Julianehảb batholith. The pelites, which are common on both sides of inner Danell Fjord at some distance from the batholith, are locally so well preserved in spite of tight to isoclinal folding that thick series of graded turbidites can easily be recognised. The intensity of metamorphism and degree of partial melting in the pelites generally increases southwards, but andalusite and cordierite crystals along axial plane cleavages of early folds (even in the pelites most proximal to the batholith) indicate that the high thermal gradient in the region was present from an early stage of deformation.

Arkosic psammites form the bulk of the psammite zone. 


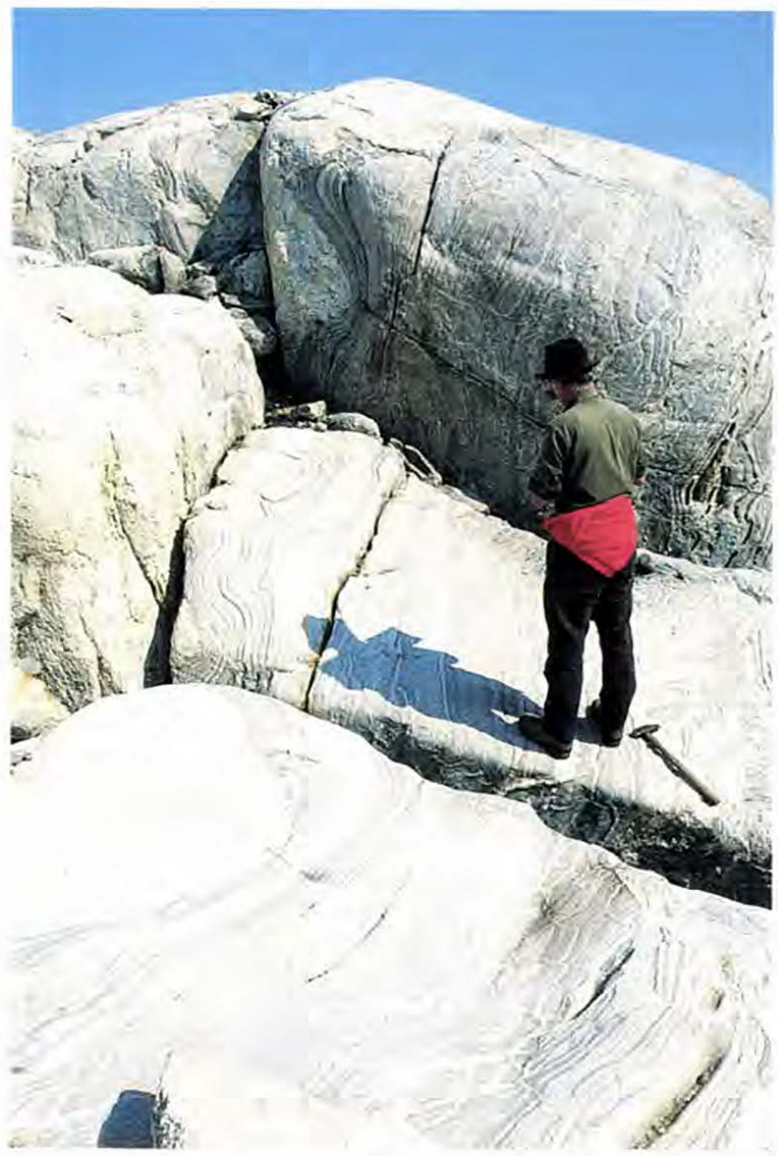

Fig. 2. Migmatised psammite with thin pelitic horizons northwest of ouler Danell Fjord.

but their stratigraphic thickness has not been established due to their uniform appearance, complex fold structures, and the increasing degree of migmatisation towards the south (Figs 2 and 3). In this part of the psammite zone there are white migmatitic granites, in which only thin, evenly distributed wisps of recognisable psammite are left. Small areass of psammite north of Danell Fjord, where anatexis is less extensive, contain al variety of well-preserved sedimentary structures, orientated right way up. Thin calcareous horizons occur in most of the psammite zone and can in places be followed for many kilometres. Local, up to a few hundred metres thick units of strongly deformed metavolcanic rocks also occur, and syntectonic dykes of the appinite suite are common throughout the psammite zone, as well as in the batholith. In the central part of the psammite zone south of Kutsey Fjord an inverted conglomerate bed rich in vein quartz clasts of unknown provenance wass found, which has an outcrop areal of several square kilometres and presumably forms part of an early nappe which cannot be completely delined. South of Lindenow Fjord the psammites give way to extensive pelitic rocks, which generally appear (o) rest conformably on the psammites. The structure of the psammite zone is as yet not properly understood, but appears to consist of alternating structural domains with respectively north-easterly and easterly trends. Upright to north-vergent, tight folds with shallow northeasterly to easterly plunges are very common. Although many of the outcrops visited in 1994 seem to have been affected by only one fold phase there is local evidence of superimposed folding.

A number of locialities of potential economic interest were investigated in 1994. Analytical results are not yet available, but will be published in due course in GGU's Open tïle report series. Localities at Danell Fjord and Lindenow Fjord where stream sediments sampled in 1992 showed anomalous gold values were resampled and supplementary chip and grab samples were taken. Agglomeratic amphibolites between Kangerluluk and Danell Fjord, and south of Kutsey Fjord, were also investigated, as samples from an amphibolite horizon south of Kutsey Fjord collected in 1992 indicated a potential for gold. Pelitic rocks from within the psammite zone containing graphite and sulphides were also sampled. In addition, a major north-east trending shear zone at the head of Danell Fjord, which separates the batholith from supracrustal amphibolites, was investigated. This shear \%one hosts intense hydrothermal alteration over a width of hundreds of metres across strike. Several cycles of hydrothermal activity may have taken place, as only some of the hydrothermally altered rocks are affected by shearing, whereas others were sheared prior to alteration.

\section{The Julianchåb batholith and supracrustal rocks in the Sondre Sermilik area}

In the Sondre Sermilik area the 1994 SUPRASYD party completed the geological survey necessary for the compibation of the $1: 100(0)(0)$ map sheet $6(0)$ V.3. Studies initiated in 1993 of gold mineralisation associated with shear zone systems in the southern part of the Niayormarsuk peninsula were also continued.

The 1994 survey supplemented the general picture of the batholith obtained in 1993 (Chadwick et cl., 1994b; Garde \& Schønwandt, 1994). A regional boundary was located in the vicinity of Igaliko Fjord between leucocratic granites to the north-west and the main, predominantly granodioritic part of the batholith to the south-east. It was also observed that the latter can be divided into three belts. From north-west to south-east these are a belt of granodiorite with common decimetre-sized dioritic inclusions. a belt of granodiorite with numerous syntectonic dioritic dykes of the appinite suite, and a belt of granodiorite with kilometre-sized and larger dioritic intrusives.

The south-eastern part of the map sheet area consists of 


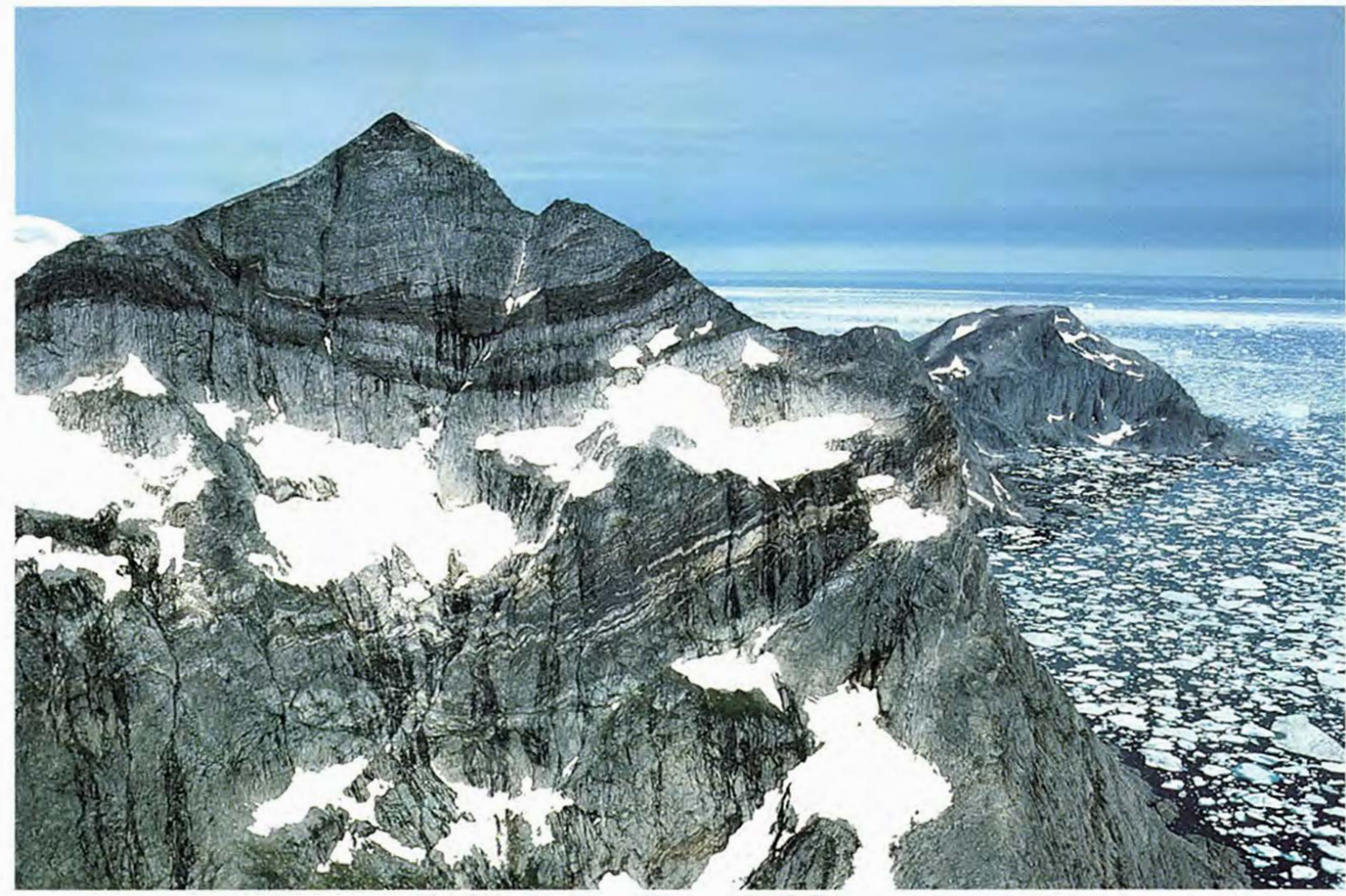

Fig. 3. Halsbåndet mountain ("the necklace") north of outer Danell Fjord, consisting of migmatised psammite with pelitic intercalations.

supracrustal rocks. The assembly of polymict conglomerates, highly strained agglomeratic amphibolites, and pelitic and arkosic psammitic rocks closely resembles successions in the proximal part of the psammite zone in the east. The supracrustal rocks occur in a rugged area of alpine relief, where geological photogrammetry (using the multimodel method, Ducholm, 1992) greatly aided the field work.

\section{Gold-bearing shear zones within the Julianehåb batholith}

An important outcome of the 1993 field work was the recognition that the Julianehåb batholith contains several major north-east trending, sinistral transcurrent shear zones, several of which are more than $500 \mathrm{~m}$ wide. The most prominent of these is the Sârdloy shear zone (Fig. 1), a 1.5 $\mathrm{km}$ wide, subvertical belt of predominantly mylonites and ultramyionites described by Chadwick et al. (1994b) (see also Windley, 1991). The Matorsuay high strain zone c. 4 $\mathrm{km}$ south-east of the Sârdloy shear zone consists of orthogneisses formed by ductile deformation of batholith granitoids. The major north-east trending shear zones (and associated second-order shear \%ones in various directions) form an integral part of the Julianehåb batholith and do not separate differem terranes as previously suggested by Windley (1991) for the Sârdloq shear zone. The shear zones commonly contain quart\% veins and hydrothermal alteration zones, which appear to have developed at high levels during late stages of the emplacement of the batholith.

One of the larger north-east trending shear zones, the Nanisiay shear zone in the eastern part of the Niayornarsuk peninsula (Stendal et al., in press), is located in the part of the batholith generally characterised by granodiorite with appinite dykes. This area contains enclaves up to a few hundred metres in size of fine-grained, feldspar-phyric, commonly strongly deformed felsic rocks of supposed subvolcanic origin, suggesting that this part of the batiolith represents some of its epizone. Stream sediment geochemistry (Stendal et al., in press) in the areas surrounding the Nanisiaq shear zone indicates a general gold enrichment along the shear zone. Across the Nanisiay shear zone there is a change in major and trace element patterns in stream sediment, which may reflect the increased abundance of dioritic rocks in the third of the above mentioned batholith belts. A major magnetic gradient is also located here (Thorning et al., 1994), with higher magnetic values to the west.

Several stream sediment gold anomalies are located 
along the Nanisiaq shear zone, and here the following types of gold-bearing siliceous veins or shear zones have been recognised (Stendal et al., in press): silicified shear zones with gold associated with galena and arsenopyrite; gold-bearing quartz veins almost devoid of sulphides; and molybdenite-bearing quartz veins with trace amounts of gold. Of the larger shear zones in the Søndre Sermilik area only the Nanisiaq shear zone and associated second-order shear zones show a combination of stream sediment gold anomalies, hydrothermal alteration and gold mineralisation, indicating that this shear zone is a significant gold exploration target.

\section{Future perspectives}

The current SUPRASYD project is a major step towards a general re-evaluation of the Ketilidian orogen, and it is intended to complete the ongoing investigations between latitudes $60^{\circ} 30^{\prime}$ and $61^{\circ} \mathrm{N}$ in South-East Greenland during a field season planned for 1996. In the meantime the Greenland Home Rule authority intends to carry out an aeromagnetic survey of part of the Julianehåb batholith in 1995. It is hoped that this will reveal a correlation of shear zones across the ice cap and expand the shear zone related exploration target for gold within the batholith. Several other important aspects of Ketilidian orogeny, such as volcanism and the structural development of the border zones in the south-west and north-east, an explanation for the high thermal gradient in the fore-arc basin, and a reappraisal of the rapakivi suite of plutons, will have to be left for future projects.

\section{References}

Allaart, J. H. 1975: Geological map of Greenland 1:500 000 sheet 1, Sydgrønland. Copenhagen: Grønlands geologiske Undersøgelse.

Allaart, J. H. 1976: Ketilidian mobile belt in South Greenland. In Escher, A. \& Watt, W. S. (ed.) Geology of Greenland, 121151. Copenhagen: Grønlands geologiske Undersøgelse.

Chadwick, B. \& Garde, A. A. in press: Palaeoproterozoic ob- lique plate convergence in South Greenland: a re-appraisal of the Ketilidian orogen. In Brewer, T. S. \& Atkin, B. P. (ed.) Spec. Pub. Geol. Soc., London. (submitted 18th June, 1994)

Chadwick, B., Erfurt, P., Frith, R. A., Nielsen, T. F. D., Schønwandt, H. K. \& Stendal, H. 1994a: Re-appraisal of the Ikermit supracrustal suite of the Ketilidian border zone in SouthEast Greenland. Rapp. Grønlands geol. Unders. 163, 23-33. Chadwick, B., Erfurt, P., Frisch, T., Frith, R. A., Garde, A. A., Schønwandt, H. K., Stendal, H. \& Thomassen, B. 1994b: Sinistral transpression and hydrothermal activity during emplacement of the Early Proterozoic Julianehåb batholith, Ketilidian belt, South Greenland. Rapp. Grønlands geol. Unders. 163, $5-22$.

Dueholm, K. S. 1992: Geologic photogrammetry using standard small-frame cameras. Rapp. Grønlands geol. Unders. 156, 7-17.

Garde, A. A. \& Schønwandt, H. K. 1994: Project SUPRASYD 1993 - granitic rocks and shear zones with possible gold potential, Julianehåb batholith, South Greenland. Rapp. Grønlands geol. Unders. 160, 28-31.

Kalsbeek, F., Larsen, L. M. \& Bondam, J. 1990: Descriptive text to 1:500 000 sheet 1, Sydgrønland. 36 pp. Copenhagen: Grønlands Geologiske Undersøgelse.

Nielsen, T. F. D., Chadwick, B., Dawes, P. R., Frith, R. A. \& Schønwandt, H. K. 1993: Project SUPRASYD 1992: opening season in the Ketilidian of South Greenland. Rapp. Grønlands geol. Unders. 159, 25-31.

Steenfelt, A., Dam, E. \& Erfurt, P. 1992: Reconnaissance geochemical mapping of eastern South Greenland $\left(60^{\circ} 30^{\prime}\right.$ to $\left.62^{\circ} 30^{\prime} \mathrm{N}\right)$. Open File Ser. Grønlands geol. Unders. 92/10, 12 pp.

Stendal, H., Grahl-Madsen, L., Olsen, H. K., Schønwandt, H. K. \& Thomassen, B. in press: Gold exploration in the early Proterozoic Ketilidian orogen, South Greenland. (Manuscript submitted to Mineral exploration '94, the Journal of the Geological Society of CIM - Exploration and Mining Geology).

Thorning, L., Tukiainen, T. \& Steenfelt, A. (ed.) 1994: Regional compilations of geoscience data from the Kap Farvel-Ivittuut area, South Greenland. Thematic Map Ser: Grønlands geol. Unders. 94/1.

Windley, B. F. 1991: Early Proterozoic collision tectonics, and rapakivi granites as intrusions in an extensional thrust-thickened crust: the Ketilidian orogen, South Greenland. Tectonophysics 195, 1-10.

A. A. G. \& H. K. S., Geological Survey of Denmark and Greenland, Copenhagen 